\title{
Correlation and Path Coefficient Analysis in Brinjal (Solanum melongena L.)
}

\author{
Sandeep Yadav*, V.B. Singh, Rohit Maurya and Vivek Thapliyal \\ ${ }^{1}$ Department of Vegetable Science College of Horticulture and Forestry, Narendra Deva \\ University of Agriculture and Technology, Kumarganj, (Faizabad-224 229 (U.P.), \\ ${ }^{2}$ GBPUAT Pantnagar, (U.K.), India \\ *Corresponding author
}

\begin{abstract}
A B S T R A C T
Experimental material for the study was consisted of 32 genotypes of two groups (long purple and round purple) including three checks (Punjab Sadabahar, Navina and Swarna

Keywords

Brinjal (Solanum melongena L.), Character association, Path analysis and Quality parameters

Article Info

Accepted:

26 October 2018

Available Online:

10 November 2018

Mani). The experiment was executed at Main Experiment, Station of Department of Vegetable Science, Narendra Deva University of Agriculture and Technology, Narendra Nagar (Kumarganj), Faizabad, during Kharif 2015. The experiment was conducted in Randomized Complete Block Design with three replications. Each treatment consisted of 20 plants in two rows, having spacing of $60 \times 45 \mathrm{~cm}$ with net plot size of $4.5 \times 1.2 \mathrm{~m}^{2}$. Genotypic correlation coefficient was similar in nature and higher in magnitude than the corresponding phenotypic correlation coefficient for most of the traits. Total fruit yield per plant had exhibited highly significant and positive association with fruits per plant (0.670) and total fruit yield per plant is significantly but negatively correlated with fruit length (-0.348). High magnitude of positive direct effect on fruit yield was exerted by no fruits per plant (1.19) followed by average fruit weight $(0.65)$, fruit circumference $(0.16)$ and the negative direct effects on total yield were showed by secondary branches per plant $(-0.057)$, days to first fruit harvest(-0.11), plant height $(-0.11)$ and fruit length $(-0.159)$ but were substantially low. The characters identified above as important direct and indirect yield components merit due consideration in formulating selection strategy in brinjal for selection of high yielding varieties.
\end{abstract}

\section{Introduction}

Brinjal or eggplant (Solanum melongena L., $2 n=2 x=24)$ is one of the most popular Solanaceous vegetable crops. It is worldwide known as aubergine or guinea squash which is one of the most popular and major vegetable crop in India and other parts of the world. It is probably originated in India and showed secondary diversity in South East Asia.
Solanum incanum, a wild species and having wide distribution in at least 10 habitats in India is the progenitor of the cultivated species, Solanum melongena. The first record of brinjal in India was during 300 B.C. to 300 A.D. Brinjal is being cultivated in India over an area of 0.68 million ha with an average annual production of 12.70 million tonnes and productivity of $18.26 \mathrm{mt} / \mathrm{ha}$. It is distributed in Orissa, Bihar, Karnataka, West Bangal, 
Andhra Pradesh, Maharashtra and Utter Pradesh. In Uttar Pradesh, brinjal is being cultivated on an area of 4.10 lakh ha with annual production of 136.16 lakh tonnes (Anon., 2016). Brinjal or eggplant is a perennial but grown commercially as annual crop. Inflorescence is often solitary but some time it constitutes a cluster of 2-5 flowers. Solitary or clustering nature of inflorescence is a varietal character. Flower is complete and hermaphrodite. Heterostyly is a common feature, and fruit setting flower consist of long $(70-86.7 \%)$ and medium styled (12-55.6\%) flower. The non-fruit setting flowers consist of short styled and pseudo styled. Brinjal contain certain medicinal properties like white brinjal is said to be good for diabetic patients (Choudhary, 1976).It has also been recommended as an excellent remedy for those suffering from liver complaint. One hundred gram edible portion of brinjal fruit contains $92.7 \%$ moisture, $24.0 \%$ calories, $4.0 \%$ carbohydrates, $1.4 \mathrm{~g}$ protein, $0.3 \mathrm{~g}$ fats, $1.3 \mathrm{~g}$ fibers, 124.0 (I.U.) Vitamin A and 12.0 mg Vitamin $\mathrm{C}$ (Chen and $\mathrm{Li}, 1996)$. It also contains $52.0 \mathrm{mg}$ chlorine, $47.0 \mathrm{mg}$ phosphorus, $44.0 \mathrm{mg}$ sulphur and other minerals (Aykroyd, 1963).A study of correlation between different characters provides an idea of association. It could be effectively exploited to formulate selection strategies for improving yield and quality. Association of characters like yield, its components, and other economical traits is important for making selection in the breeding programme. It suggests the advantage of a scheme of selection for more than one character at a time (Kalloo, 1994). Correlation coefficient analysis measures the mutual relationship between various plant characters and determines the component characters, on which selection can be based for genetic improvement in yield, whereas, path analysis split the correlation coefficients into direct and indirect effects, thereby assists in the selection of genotype. On the basis of these studies, the quantum importance of individual character will facilitate the selection programme for better gains. Path analysis also measures the relative importance of causal factors involved. This is simply a standardized partial regression analysis, where in total correlation values were subdivided into causal factors (Shipley, 2000).

\section{Materials and Methods}

The field experiment under present investigation was conducted during autumnwinter season 2015-2016, at the Main Experiment Station, Department of Vegetable Science, N.D. University of Agriculture and Technology Narendra Nagar (Kumarganj), Faizabad (U.P.). The experimental field had sandy loam soil, low in organic carbon, nitrogen, medium in phosphorus, potash, and slightly alkaline in nature with $\mathrm{pH}$ 8.5.The mechanical composition of soil was 60.9 per cent, 27.8 per cent silt and 11.3 per cent clay. The experimental material for the present investigation comprised of 32 genotypes of brinjal collected from different places in India and being maintained at Main Experiment Station in the Department of Vegetable Science, N.D. University of Agriculture \& Technology, (Narendra Nagar) Kumarganj, Faizabad (U.P).The experiment was conducted in Randomized Complete Block Design with three replications during autumn-winter season in 2015-2016 to assess the performance of 32 genotypes. Each treatment consisted of two rows. Ten plants were maintained in each row and replicated thrice. Transplanting was done at a spacing of $60 \mathrm{~cm}$ between row to row and $45 \mathrm{~cm}$ plant to plant having net plot size of $4.5 \times 1.2 \mathrm{~m}^{2}$. The seed were sown in nursery bed on 03-08-2015 and transplanted on 04-09-2015. All the recommended agronomic package of practices and plant protection measures were followed to raise a good crop. Observations recorded Days to 50 per cent flowering, Plant height $(\mathrm{cm})$, Number 
of primary branches per plant, Number of secondary branches per plant, Days to first fruit harvest, Fruit length $(\mathrm{cm})$, Fruit circumference $(\mathrm{cm})$, Number of fruits per plant, Average fruit weight $(\mathrm{g})$, Total fruit yield per plant $(\mathrm{kg})$.

\section{Results and Discussion}

\section{Correlation coefficient}

The phenotypic and genotypic correlation coefficient computed among the ten characters under study has been present in table 1 and 2 . In general, genotypic correlation coefficient, were higher than the corresponding phenotypic correlation, suggesting therefore, a strong inherent relationship in different pairs of characters in brinjal genotypes. The most important trait, total fruit yield per plant had exhibited highly significant and positive phenotypic correlation with fruits per plant (0.670) and total fruit yield per plant is significantly but negatively correlated with fruit length (-0.348). Average fruit weight is significantly and positively correlated with fruit circumference $(0.385)$ while no. of fruits per plant(-0.732) and fruit length(-0.347) were found significantly but negatively correlated. Fruit circumference is significantly and positively correlated with days to $50 \%$ flowering (0.354) and days to first fruit harvest (0.403), while fruit length(-0.708) was found significantly but negative correlated. Fruit length is found significantly but negatively correlated with days to $50 \%$ flowering (-0.522) and days to first fruit harvest $(-0.400)$. Plant height is found significantly but negatively correlated with days to $50 \%$ flowering. Days to first fruit harvest is found significantly and positively correlated with days to $50 \%$ flowering $(0.756)$. Secondary branches per plant is found significantly and positively correlated with primary branches per plant $(0.777)$.
The nature and magnitude of association between yield and its component traits is necessary for effective selection in advance generations. Nature of population under consideration and the magnitude of correlation coefficient could often be influenced by the choice of the individuals upon which the observations are made correlations between pairs of characters are due to linkage of genes or pleiotropy of genes. Therefore, selection of one traits influence the other linked or pleiotropically affected traits. Considerable importance has been attached to correlation studies in the plant improvement because they are helpful in making effective selection. In the present study, correlations between ten characters were worked out in all possible combinations at phenotypic and genotypic levels and are presented in table 1 and 2. In general, the magnitudes of genotypic correlation coefficients were similar in nature and higher in magnitude than the corresponding values of the phenotypic correlation coefficients. This indicated a strong genetic association between the traits and the phenotypic expression which was suppressed due to environmental influence. The previous studies also suggested that both genotypic and phenotypic correlation were similar in direction as reported by Sharma et al., (2000) and Goto et al., (1953).

A perusal of data (Table 1 and 2) revealed that the most important trait, total fruit yield per plant had exhibited highly significant and positive phenotypic correlation with fruits per plant and total fruit yield per plant is significantly but negatively correlated with fruit length. Average fruit weight is significantly and positively correlated with fruit circumference while no. of fruits per plant and fruit length were found significantly but negatively correlated. Fruit circumference is significantly and positively correlated with days to $50 \%$ flowering and days to first fruit harvest, while fruit length was found 
significantly but negative correlated. Fruit length is found significantly but negatively correlated with days to $50 \%$ flowering and days to first fruit harvest. Plant height is found significantly but negatively correlated with days to $50 \%$ flowering. Days to first fruit harvest is found significantly and positively correlated with days to $50 \%$ flowering. Secondary branches per plant is found significantly and positively correlated with primary branches per plant. Similar finding has also been reported by many workers viz. for fruit yield (Naliyadhara et al., 2007; Singh et al., 1983; Krusteva et al., 1985; Choudhary et al., 2013), for average fruit weight (Krusteva, 1985; Jadhav et al., 2009), for primary branches per plant (Kumar et al., 1990 and Karak et al., 2012), fruit circumference (Bora and Shadeque, 1993; and Pandey et al., 2016) and fruit length (Pandey et al., 2016).

\section{Path coefficient analysis}

The path coefficient analysis was carried out from phenotypic and genotypic correlation coefficient to resolve direct and indirect effects of nine characters on fruit yield per plant. The direct and indirect effect of different characters on fruit yield at phenotypic and genotypic level has been presented in table 3 and 4 . The genotypic direct and indirect effects of most of the traits were similar in nature and higher in magnitude. The higher magnitude of positive direct effect on fruit yield was exerted by no. of fruits per plant (1.19) followed by average fruit weight (0.65) and fruit circumference (0.16). The negative direct effect on yield was showed by secondary branches per plant (-0.057), days to first fruit harvest (-0.11), plant height $(-0.11)$ and fruit length $(-0.159)$ but were substantially low. The number of fruits per plant was not only found to have maximum direct effect on total fruit yield per plant but it also contributed substantial positive indirect effect for secondary branches per plant (0.14), followed by fruit length (0.134) and primary branches per plant (0.132) and negative indirect effect for fruit circumference (-0.29) and days to first fruit harvest $(-0.25)$ towards total fruit yield per plant. The positive or negative indirect contributions by rest of the traits were negligible. The estimate of the residual factor was very low (0.3830). Path coefficient is simply standardized partial regression coefficient which splits the correlation coefficient into the measures of the direct and indirect effects of a set of independent variables on the dependent variable. This analysis provides a method for separating out direct and indirect effect of causal factors which affect the yield. The direct and indirect effects of different characters on total fruit yield at phenotypic and genotypic level has been presented in table 3 and 4 . The genotypic direct and indirect effects of most of the traits were similar in nature and higher in magnitude than the respective phenotypic direct and indirect effects. The higher magnitude of positive direct effect on total fruit yield was exerted by fruits per plant followed by average fruit weight, fruit circumference. The negative direct effect on yield was showed by secondary branches per plant, days to first fruit harvest, plant height and fruit length but were substantially low. The number of fruits per plant was not only found to have maximum direct effect on total fruit yield per plant but it also contributed substantial positive indirect effect for secondary branches per plant, followed by fruit length and primary branches per plant and negative indirect effect for fruit circumference and days to first fruit harvest towards total fruit yield per plant. The positive or negative indirect contributions by rest of the traits were negligible. The estimate of the residual factor was very low. Therefore, during selection these characters should also be taken into consideration. Similar results had also been reported by Bansal and Mehta (2008); Jadhav et al., (2009), Singh et al., (2012) and Neeraj et al., (2017). 
Table.1 Estimates of phenotypic correlation coefficients among ten characters in brinjal germplasm

\begin{tabular}{|c|c|c|c|c|c|c|c|c|c|c|}
\hline $\begin{array}{l}\text { S. } \\
\text { No. }\end{array}$ & Characters & $\begin{array}{ll}\text { No. } & \text { of } \\
\text { secondary } & \\
\text { branches } & \text { per } \\
\text { plant } & \end{array}$ & $\begin{array}{l}\text { Days to } \\
50 \% \\
\text { flowering }\end{array}$ & $\begin{array}{l}\text { Days to first } \\
\text { fruit harvest }\end{array}$ & $\begin{array}{l}\text { Plant height } \\
(\mathrm{cm})\end{array}$ & $\begin{array}{l}\text { Fruit } \\
\text { length } \\
(\mathrm{cm})\end{array}$ & $\begin{array}{l}\text { Fruit } \\
\text { circumference } \\
(\mathrm{cm})\end{array}$ & $\begin{array}{l}\text { No. of } \\
\text { fruits per } \\
\text { plant }\end{array}$ & $\begin{array}{l}\text { Average } \\
\text { fruit weight } \\
(\mathrm{gm})\end{array}$ & $\begin{array}{l}\text { Total fruit } \\
\text { yield per } \\
\text { plant }(\mathrm{kg})\end{array}$ \\
\hline 1. & $\begin{array}{l}\text { Number of primary } \\
\text { branches per plant }\end{array}$ & $0.7774 * *$ & 0.1111 & 0.0841 & 0.1834 & -0.0746 & -0.0105 & 0.1115 & -0.0140 & 0.0853 \\
\hline 2. & $\begin{array}{l}\text { Number of secondary } \\
\text { branches per plant }\end{array}$ & & 0.0027 & 0.0335 & 0.0990 & -0.0351 & 0.0847 & 0.1236 & -0.0642 & 0.0715 \\
\hline 3. & Days to $50 \%$ flowering & & & $0.7569 * *$ & $-0.3084 *$ & $-5.5223 * *$ & $0.3542 *$ & -0.1633 & 0.2771 & 0.0953 \\
\hline 4. & Days to first fruit harvest & & & & -0.1780 & $-0.4006^{*}$ & $0.4032 *$ & -0.2128 & 0.2230 & -0.0586 \\
\hline 5. & Plant height $(\mathrm{cm})$ & & & & & 0.1737 & -0.2774 & 0.0162 & -0.1331 & -0.2423 \\
\hline 6. & Fruit length $(\mathrm{cm})$ & & & & & & $-0.7081 * *$ & 0.1127 & $-0.3472 *$ & $-0.3480 *$ \\
\hline 7. & Fruit circumference $(\mathrm{cm})$ & & & & & & & -0.2484 & $0.3853^{*}$ & 0.2161 \\
\hline 8. & No. of fruits per plant & & & & & & & & $-0.7327 * *$ & $0.6700 * *$ \\
\hline 9. & Average fruit weight (gm) & & & & & & & & & -0.1051 \\
\hline
\end{tabular}

*, **- Significant at $5 \%$ and $1 \%$ probability level, respectively 
Table.2 Estimates of genotypic correlation coefficients among ten characters in brinjal germplasm

\begin{tabular}{|c|c|c|c|c|c|c|c|c|c|c|}
\hline $\begin{array}{l}\text { S. } \\
\text { No. }\end{array}$ & Characters & $\begin{array}{c}\text { No. of } \\
\text { secondary } \\
\text { branches per } \\
\text { plant }\end{array}$ & $\begin{array}{l}\text { Days to } \\
50 \% \\
\text { flowering }\end{array}$ & $\begin{array}{l}\text { Days to } \\
\text { first fruit } \\
\text { harvest }\end{array}$ & $\begin{array}{l}\text { Plant } \\
\text { height } \\
(\mathrm{cm})\end{array}$ & $\begin{array}{l}\text { Fruit } \\
\text { length } \\
(\mathrm{cm})\end{array}$ & $\begin{array}{c}\text { Fruit } \\
\text { circumference } \\
(\mathrm{cm})\end{array}$ & $\begin{array}{l}\text { No. of } \\
\text { fruits per } \\
\text { plant }\end{array}$ & $\begin{array}{l}\text { Average } \\
\text { fruit weight } \\
\text { (gm) }\end{array}$ & $\begin{array}{c}\text { Total fruit } \\
\text { yield per plant } \\
(\mathrm{kg})\end{array}$ \\
\hline 1. & $\begin{array}{c}\text { Number of } \\
\text { primary branches } \\
\text { per plant }\end{array}$ & 0.8420 & 0.1617 & 0.1141 & 0.2230 & -0.066 & -0.0132 & 0.1084 & -0.0119 & 0.0876 \\
\hline 2. & $\begin{array}{c}\text { Number of } \\
\text { secondary } \\
\text { branches per plant }\end{array}$ & & 0.0325 & 0.0104 & 0.0799 & -0.055 & 0.0825 & 0.1183 & -0.0722 & 0.0642 \\
\hline 3. & $\begin{array}{l}\text { Days to } 50 \% \\
\text { flowering }\end{array}$ & & & 0.9238 & -0.3382 & -0.621 & 0.4326 & -0.1828 & 0.3137 & 0.1244 \\
\hline 4. & $\begin{array}{c}\text { Days to first fruit } \\
\text { harvest }\end{array}$ & & & & -0.2361 & -0.489 & 0.4459 & -0.2602 & 0.2453 & -0.0796 \\
\hline 5. & Plant height $(\mathrm{cm})$ & & & & & 0.1851 & -0.3138 & 0.0195 & -0.1450 & -0.2686 \\
\hline 6. & Fruit length $(\mathrm{cm})$ & & & & & & -0.7621 & 0.1189 & -0.3582 & -0.3700 \\
\hline 7. & $\begin{array}{c}\text { Fruit } \\
\text { circumference } \\
(\mathrm{cm})\end{array}$ & & & & & & & -0.2721 & 0.4007 & 0.2156 \\
\hline 8. & $\begin{array}{l}\text { No. of fruits per } \\
\text { plant }\end{array}$ & & & & & & & & -0.7498 & 0.6653 \\
\hline 9. & $\begin{array}{l}\text { Average fruit } \\
\text { weight (gm) }\end{array}$ & & & & & & & & & -0.1113 \\
\hline
\end{tabular}




\section{Int.J.Curr.Microbiol.App.Sci (2018) 7(11): 3182-3190}

Table.3 Direct and indirect effect of nine characters on fruit yield per plant $(\mathrm{kg})$ at phenotypic level in brinjal

\begin{tabular}{|c|c|c|c|c|c|c|c|c|c|c|c|}
\hline $\begin{array}{l}\text { S. } \\
\text { No. }\end{array}$ & Characters & $\begin{array}{l}\text { No. of } \\
\text { primary } \\
\text { branches } \\
\text { per plant }\end{array}$ & $\begin{array}{l}\text { No. of } \\
\text { secondary } \\
\text { branches } \\
\text { per plant }\end{array}$ & $\begin{array}{l}\text { Days to } \\
50 \% \\
\text { flowering }\end{array}$ & $\begin{array}{l}\text { Days to } \\
\text { first } \\
\text { fruit } \\
\text { harvest }\end{array}$ & $\begin{array}{l}\text { Plant } \\
\text { height } \\
(\mathrm{cm})\end{array}$ & $\begin{array}{l}\text { Fruit } \\
\text { length } \\
(\mathrm{cm})\end{array}$ & $\begin{array}{l}\text { Fruit } \\
\text { circumference } \\
(\mathrm{cm})\end{array}$ & $\begin{array}{l}\text { No. of } \\
\text { fruits } \\
\text { per } \\
\text { plant }\end{array}$ & $\begin{array}{l}\text { Average } \\
\text { fruit } \\
\text { weight }(\mathrm{gm})\end{array}$ & $\begin{array}{l}\text { Total } \\
\text { fruit } \\
\text { yield per } \\
\text { plant } \\
(\mathrm{kg})\end{array}$ \\
\hline 1. & $\begin{array}{l}\text { Number of primary branches per } \\
\text { plant }\end{array}$ & 0.0254 & -0.0447 & 0.0016 & -0.0093 & -0.0214 & 0.0119 & -0.0017 & 0.1327 & -0.0091 & 0.0853 \\
\hline 2. & $\begin{array}{l}\text { Number of secondary branches per } \\
\text { plant }\end{array}$ & 0.0198 & -0.0575 & 0.0000 & -0.0037 & -0.0116 & 0.0056 & 0.0136 & 0.1427 & -0.0419 & 0.0715 \\
\hline 3. & Days to $50 \%$ flowering & 0.0028 & -0.0002 & 0.0143 & -0.0840 & 0.0361 & 0.0831 & 0.0568 & -0.1943 & 0.1806 & 0.0953 \\
\hline 4. & Days to first fruit harvest & 0.0021 & -0.0019 & 0.0109 & -0.1109 & 0.0208 & 0.0638 & 0.0646 & -0.2533 & 0.1454 & -0.0586 \\
\hline 5. & Plant height $(\mathrm{cm})$ & 0.0047 & -0.0057 & -0.0044 & 0.0197 & -0.1169 & -0.0276 & -0.0445 & 0.0193 & -0.0868 & -0.2423 \\
\hline 6. & Fruit length $(\mathrm{cm})$ & -0.0019 & 0.0020 & -0.0075 & 0.0444 & -0.0203 & -0.1591 & -0.1135 & 0.1342 & -0.2264 & -0.3480 \\
\hline 7. & Fruit circumference $(\mathrm{cm})$ & -0.0003 & -0.0049 & 0.0051 & -0.0447 & 0.0324 & 0.1127 & 0.1603 & -0.2957 & 0.2512 & 0.2161 \\
\hline 8. & No. of fruits per plant & 0.0028 & -0.0071 & -0.0023 & 0.0236 & -0.0019 & -0.0179 & -0.0398 & 1.1904 & -0.4777 & 0.6700 \\
\hline 9. & Average fruit weight (gm) & -0.0004 & 0.0037 & 0.0040 & -0.0247 & 0.0156 & 0.0553 & 0.0617 & -0.8722 & 0.6519 & -0.1051 \\
\hline
\end{tabular}




\section{Int.J.Curr.Microbiol.App.Sci (2018) 7(11): 3182-3190}

Table.4 Direct and indirect effect of nine characters on fruit yield per plant $(\mathrm{kg})$ at genotypic level in brinjal

\begin{tabular}{|c|c|c|c|c|c|c|c|c|c|c|c|}
\hline $\begin{array}{l}\text { S. } \\
\text { No. }\end{array}$ & Characters & $\begin{array}{l}\text { No. of } \\
\text { primary } \\
\text { branches } \\
\text { per plant }\end{array}$ & $\begin{array}{l}\text { No. of } \\
\text { secondary } \\
\text { branches } \\
\text { per plant }\end{array}$ & $\begin{array}{l}\text { Days to } \\
50 \% \\
\text { flowering }\end{array}$ & $\begin{array}{l}\text { Days to } \\
\text { first } \\
\text { fruit } \\
\text { harvest }\end{array}$ & $\begin{array}{l}\text { Plant } \\
\text { height } \\
(\mathrm{cm})\end{array}$ & $\begin{array}{l}\text { Fruit } \\
\text { length } \\
(\mathrm{cm})\end{array}$ & $\begin{array}{l}\text { Fruit } \\
\text { circumference } \\
(\mathrm{cm})\end{array}$ & $\begin{array}{l}\text { No. of } \\
\text { fruits } \\
\text { per } \\
\text { plant }\end{array}$ & $\begin{array}{l}\text { Average } \\
\text { fruit } \\
\text { weight(gm) }\end{array}$ & $\begin{array}{l}\text { Total } \\
\text { fruit yield } \\
\text { per plant } \\
(\mathrm{kg})\end{array}$ \\
\hline 1. & $\begin{array}{l}\text { Number of primary branches per } \\
\text { plant }\end{array}$ & 0.1167 & -0.1227 & 0.0393 & -0.0401 & 0.0284 & 0.0080 & -0.0029 & 0.1248 & -0.0072 & 0.0876 \\
\hline 2. & $\begin{array}{l}\text { Number of secondary branches } \\
\text { per plant }\end{array}$ & 0.0983 & -0.1457 & 0.0079 & -0.0036 & 0.0102 & 0.0067 & 0.0182 & 0.1363 & -0.0436 & 0.0642 \\
\hline 3. & Days to $50 \%$ flowering & 0.0189 & -0.0047 & 0.2428 & -0.3247 & 0.0430 & 0.0750 & 0.0954 & $0 . \overline{2106}$ & 0.1893 & 0.1244 \\
\hline 4. & Days to first fruit harvest & 0.0133 & -0.0015 & 0.2243 & -0.3515 & 0.0300 & 0.0591 & 0.0984 & 0.2998 & 0.1480 & -0.0796 \\
\hline 5. & Plant height $(\mathrm{cm})$ & 0.0260 & -0.0116 & -0.0821 & 0.0830 & 0.1272 & 0.0223 & -0.0692 & 0.0225 & -0.0875 & -0.2686 \\
\hline 6. & Fruit length $(\mathrm{cm})$ & -0.0078 & 0.0080 & -0.1508 & 0.1722 & 0.0236 & $0 . \overline{1207}$ & -0.1681 & 0.1370 & -0.2162 & -0.3700 \\
\hline 7. & Fruit circumference $(\mathrm{cm})$ & -0.0015 & -0.0120 & 0.1050 & -0.1567 & 0.0399 & 0.0920 & 0.2206 & $0 . \overline{3135}$ & 0.2418 & 0.2156 \\
\hline 8. & No. of fruits per plant & 0.0126 & -0.0172 & -0.0444 & 0.0915 & $\stackrel{-}{0.0025}$ & 0.0144 & -0.0600 & 1.1522 & -0.4525 & 0.6653 \\
\hline 9. & Average fruit weight (gm) & -0.0014 & 0.0105 & 0.0762 & -0.0862 & 0.0184 & 0.0432 & 0.0884 & 0.8640 & 0.6035 & -0.1113 \\
\hline
\end{tabular}

$\mathrm{R}^{2}=0.8849$, Residual effect $=0.3393$ 


\section{References}

Aykroyd, W.R. (1963). The nutritive value of Indian foods and planning of satisfactory diet. ICMR Special Rep. Series.No.42.

Bansal, S. and Mehta, A.K. (2008).Phenotypic correlation and path coefficient analysis of some quantitative traits in eggplant. Indian. J. Trop. Biodiversity., 16(2): 185-190.

Choudhary, B. (1976). Vegetable, $4^{\text {th }} e d n$. National Book Trust, New Delhi, pp. 50-58.

Choudhary, P., Kumar, S. and Verma, P.P.S. (2013). Correlation and path coefficient analysis in brinjal (Solanum melongena L.). Hort Flora Resea. Spect., 2(4):346351).

Goto, K. (1953). Genetic studies on egg plant. Genetics, 2b:445-412.

Jadhav, S.T., Thawane, B.L., Rathod, D.R. and Navhale, V.C. (2009). Correlation and path analysis studies in brinjal. Ann. Pl. Physiol., 23(2):177-179.

Jadhav, S.T., Thawane, B.L., Rathod, D.R. and Navhale, V.C. (2009). Correlation and path analysis studies in brinjal. Ann. Pl. Physiol., 23(2):177-179.

Kalloo, G. (1994). Vegetable Breeding, Panima Educational Book Agency, New Delhi.

Karak, C., Ray, U., Akhtar, S., Naik, A. and Hazra, P. (2012). Genetic variation and character association in fruit yield components and quality characters in brinjal [Solanum melongena L.]. $J$.
Crop and Weed.,8(1):86-89.

Krusteva, L. (1985). Correlation in egg plant. Capsicum News Letters. No. 4:80-81.

Naliyadhara, M. V., Golani, I. J., Mehta, D. R. and Purohit, V. L. (2007).Genetic variability, correlation co-efficient and path analysis in brinjal. Orissa $J$. Hort., 35(2):92-96.

Naliyadhara, M. V., Golani, I. J., Mehta, D. R. and Purohit, V. L. (2007). Genetic variability, correlation co-efficient and path analysis in brinjal. Orissa J. Hort., 35(2): 92-96.

Pandey, P.K., Yadav, G.C.and Kumar, V. (2016).Correlation and path coefficient analysis among different characters in genotype of brinjal (Solanum melongena). Indian J. Ecol., 43(1):370372.

Sharma, T.V.R.S., Kishan, S. and Swaroop, K. (2000). Genetic variability and character association in brinjal (Solanum melongena L.). Indian. $J$. Hort., 57 (1): 59-65.

Singh, H. and Nandpuri, K.S. (1974). Genetic variability and correlation studies in egg plant (Solanum melongena L.). Punjab Agric. Univ. Res. J., 11(2):150-157.

Singh, N., Singh, D. K., Pandey, P., Panchbhaiya, A., and Rawat, M. (2017). Correlation and Path Coefficient Studies in Okra [Abelmoschus esculentus (L.) Moench]. Int. J. Curr. Microbiol. App. Sci, 6(7), 1096-1101.

\section{How to cite this article:}

Sandeep Yadav, V.B. Singh, RohitMaurya and Vivek Thapliyal. 2018. Correlation and Path Coefficient Analysis in Brinjal (Solanum melongena L.). Int.J.Curr.Microbiol.App.Sci. 7(11): 3182-3190. doi: https://doi.org/10.20546/ijcmas.2018.711.366 